\title{
A Brief Discussion on the Changes of Tax System Since China's Reform and Opening up (1978-2018)
}

\author{
Jierui $\mathrm{Jia}^{1,2}$, Junyang $\mathrm{Li}^{3}$, $\mathrm{Ke} \mathrm{Gao}^{3,4}$ \\ ${ }^{1}$ School of Public Finance and Tax, Central University of Finance and Economics, Beijing, P. R. China \\ ${ }^{2}$ School of Public Finance and Tax, Henan University of Economics and Law, Zhengzhou, P. R. China \\ ${ }^{3}$ International Ecological Economy Promotion Association, Beijing, P. R. China \\ ${ }^{4}$ Development Research Center of Shandong Provincial People's Government, Jinan, P. R. China
}

Email address:

1743131519@qq.com (Jierui Jia),928995020@qq.com (Junyang Li), gkfly@126.com (Ke Gao)

\section{To cite this article:}

Jierui Jia, Junyang Li, Ke Gao. A Brief Discussion on the Changes of Tax System Since China's Reform and Opening up (1978-2018).

American Journal of Management Science and Engineering. Vol. 4, No. 2, 2019, pp. 26-31. doi: 10.11648/j.ajmse.20190402.12

Received: February 11, 2019; Accepted: May 21, 2019; Published: June 15, 2019

\begin{abstract}
According to Chinese reform and opening up process, as well as fiscal and taxation's differences at different stages, since 1978, China's taxation reform could be divided into three stages. Every reform stage was carried out in the specific economic and political environment at that time, and a phased tax system was constructed. China's Statistical Yearbook and the financial and taxation departments' reports show that China's total tax revenue and tax structure have changed greatly in the past 40 years. The successful experience of China's tax reform is to adhere to the direction of socialist market economy, create a fair competitive environment for enterprise development, steadily implement it, and widely solicit public opinions. However, under the background of global economic integration and international tax reform, China's tax reform should further increase the proportion of direct tax, focusing on the improvement of VAT, personal income tax, real estate tax and consumption tax, and realizing the internationalization of China's tax system.
\end{abstract}

Keywords: China's Reform and Opening up, Fiscal and Taxation Reform, Tax System Design

\section{Review of the Changes of Tax System in China Since Reform and Opening-up}

\subsection{The Tax Reform During the Period of Economic Transition (1978-1993)}

\subsubsection{Background of Reform During This Period}

All departments had emancipated their minds and sought truth from facts, conscientiously summed up the experience and lessons of tax system construction since the founding of New China, and formulated the guiding ideology of working in accordance with China's national conditions and economic laws to give full play to the economic leverage of taxation. [1] Tax authorities at all levels were quickly restored and strengthened, the status of provincial tax authorities was raised, tax authorities below the provincial level have restored the system of dual leadership by local governments and superior tax authorities. The number of tax cadres had been greatly enriched. The national tax system had 179,000 personnel in 1979 and 286,000 in 1982. In 1983 and 1985, the number of tax officials increased by 40,000 and 100,000 respectively. The State Administration of Taxation was established in 1988. [2]

\subsubsection{The Scope of Tax Reform During This Period}

The finance and taxation departments prioritize the issue of foreign taxation during this period. From 1980 to 1981, the Fifth National People's Congress had successively promulgated the income tax law for sin-foreign joint ventures, the individual income tax law and the foreign enterprise income tax law. At the same time, the finance and taxation departments began to reform the profit distribution system of state-owned enterprises. In 1983, the State Council decided to try out the "replacement of profit delivery by taxes" system for state-owned enterprises nationwide, aiming at changing the system of state-owned enterprises handing over 
profits to the state into the system of paying enterprise income tax. [3] In addition, the State Council issued regulations on a series of taxes, such as value-added tax, product tax, salt tax, tariff, urban maintenance and construction tax and bonus tax for enterprises and institutions from 1984 to 1989 , so as to enhance the macro-control role of taxation in urban economic construction.

\subsubsection{The Design of Tax System During This Period}

During this period, a new tax system with goods and services tax and income tax as the main body and property tax and other taxes as the matching was built, which consists of 4 types of taxes and 37 categories of taxes. First, goods and services tax. Including product tax, value-added tax, salt tax, special consumption tax, special fuel oil tax, business tax, industrial and commercial consolidated tax and tariff. Second income tax. The state-owned enterprise income tax, state-owned enterprise regulation tax, collective-owned enterprise income tax, private enterprise income tax, foreign-invested enterprises and foreign enterprises income tax, individual income tax, income tax of urban and rural self-employed industrial and commercial households, individual income regulation tax, state-owned enterprise bonus tax, collective-owned enterprise bonus tax, undertaking unit bonus tax and state-owned enterprise salary regulation tax were included. Third, property tax, which included house property tax, urban real estate tax, urban land use tax, cultivated land use tax, deed tax, resource tax, operation tax of vehicle and ship and driving license tax on vehicle and boat. Fourth, other taxes. It included stamp duty, city maintenance and construction tax, fixed asset investment regulation tax, slaughter tax, feast tax, livestock transaction tax, market transaction tax, agricultural tax and animal husbandry tax. [4]

\subsection{The Tax Reform During the Period of Establishing the Socialist Market Economic System (1994-2012)}

\subsubsection{Background of the Tax Reform in 1994}

Although China had completed the phased tax reform, there were still some problems need to be solved urgently. The design of the income tax system was unfair and unreasonable, which showed that taxpayers of different ownership were given different treatment, while taxpayers of non-public ownership bore a heavier burden. Reformers had the idea of "replacement of profit with tax revenue", so they had formulated a high-income tax rate for state-owned enterprises and imposed a regulation tax on the profits of some large and medium-sized state-owned enterprises after paying enterprise income tax. Various income taxes had a wide tax base, high tax rates and relatively heavy legal tax burden, which were not conducive to the development of enterprises and the improvement of workers' lives. The tax categories were too complicated and the tax system design was bloated. So, the tax reform in 1994 was the largest, most extensive and most profound tax reform since the founding of New China, which had made the tax system more simplified, more standardized and fairer.

\subsubsection{Main Contents of Tax Reform in 1994}

\section{i. The Scope of the Tax Reform}

First, a comprehensive reform of the goods and services tax system had been carried out, with a more standardized value-added tax as the main body, consumption tax and business tax in parallel, and a unified goods and services tax system both inside and outside. The second was to reform the enterprise income tax system, combining various types of enterprise income tax collected separately from state-owned enterprises, collective enterprises and private enterprises into a unified enterprise income tax. The third was to reform the personal income tax system, combining the personal income tax levied on foreigners in the past, the personal income regulation tax levied on Chinese and the income tax of urban and rural self-employed industrial and commercial households into a unified personal income tax. Fourth, other taxes would be greatly adjusted, such as expanding the scope of resource tax collection, levying land value-added tax, abolishing 12 tax categories such as salt tax, special fuel oil tax and market transaction tax, and adding estate tax and securities transaction tax (these two taxes had not been levied by legislation since then). [5]

\section{ii. The Design of Tax System During This Period}

So far, China's tax system has a total of 25 kinds of taxes, namely, value-added tax, consumption tax, business tax, tariff, enterprise income tax, foreign-invested enterprises and foreign enterprise income tax, personal income tax, land value-added tax, house property tax, urban real estate tax, estate tax, urban land use tax, cultivated land use tax, deed tax, resource tax, operation tax of vehicle and ship, driving license tax on vehicle and boat, stamp duty, securities transaction tax, urban maintenance and construction tax, fixed asset investment regulation tax, slaughter tax, feast tax, agricultural tax and animal husbandry tax.

\subsubsection{Further Adjustment of Tax Reform in 1994}

\section{i. The Agricultural Tax System}

In 2005, the Standing Committee of the National People's Congress (NPC) decided to abolish the agricultural tax from 2006, which marked the end of the 2600-year Royal grain tax levied by China from the "first taxation" in the Spring and Autumn Period. In addition, from 2005 to 2006, the State Council abolished animal husbandry tax and slaughter tax successively, and levied tobacco tax on tobacco products.

\section{ii. The Goods and Services Tax System}

Since 1998, the Ministry of Finance and the State Administration of Taxation had adjusted some tax items, tax rates and tax methods of consumption tax. In 2001, the State Council decided to start levying vehicle purchase tax. In 2004, the State Council implemented new customs regulations. In 2008, the State Council promoted the change of value-added tax from "production" to "consumption" and adjusted the consumption tax in combination with the reform of petroleum taxes and fees. Since 2012, the pilot project of changing business tax to value-added tax (VAT) had been implemented. 


\section{iii. The Income Tax System}

From 1999 to 2011, the Standing Committee of the National People's Congress amended the Individual Income Tax Law five times, mainly to regulate the deduction of income from wages and salaries and the taxation of interest on savings deposits. In 2007, the National People's Congress merged the corporate income tax previously levied on domestic enterprises and foreign-funded enterprises, and the new corporate income tax law came into effect in 2008.

\section{iv. The Property Tax System}

The State Council promulgated the Provisional Regulations on Deed Tax in October 1997 and the Provisional Regulations on Ship Tonnage Tax in 2012. The Standing Committee of the National People's Congress passed a new vehicle and vessel law in 2011. From 2006 to 2009, the State Council changed the urban land use tax and cultivated land use tax collected internally into a unified tax. Since 2009, the city real estate tax levied on foreigners has been abolished, and Chinese and foreign taxpayers were required to pay house property tax uniformly.

\section{v. Some Other Taxes}

The State Council stopped collecting the fixed asset investment regulation tax in 2000 , officially abolished feast tax and fixed asset investment regulation tax in 2008 and 2013, and included foreign-invested enterprises and foreign enterprises in the scope of taxpayers of urban maintenance and construction tax since December 2010. [6]

\subsubsection{The Design of Tax System in 2012}

By 2012, China's tax system had a total of 18 kinds of taxes, which can be roughly divided into the following four categories in accordance with the object of Taxation: First, goods and services tax, which included value-added tax, consumption tax, vehicle purchase tax, business tax and tariff Second, income tax. It included enterprise income tax, personal income tax and land value-added tax. Third, property tax. It included the house property tax, urban land use tax, cultivated land use tax, deed tax, resource tax, vehicle and vessel tax and ship tonnage tax. Fourth, other taxes such as stamp duty, city maintenance and construction tax and tobacco tax. [7]

\subsection{The Tax Reform During the Period of Comprehensive Deepening Reform (Since 2013)}

\subsubsection{Background of the Tax Reform During This Period}

In November 2013, the Chinese government formed a decision to comprehensively deepen reform on several major issues. In March 2016, "the Outline of the 13th Five-Year Plan for National Economic and Social Development of the People's Republic of China" was approved by the twelfth National People's Congress. The Chinese government had formed a new guiding ideology on tax reform. It was believed that China should optimize the tax structure and stabilize the tax burden, improve the local tax system and increase the proportion of direct taxes, push forward the reform of value-added tax, consumption tax, resource tax and personal income tax, and speed up the legislation of real estate tax, improve the way of tax collection and management, clean up unreasonable charges related to enterprises and reduce the tax burden on enterprises since then.

\subsubsection{Main Contents of Tax Reform During This Period}

\section{i. The Scope of Tax Reform During This Period}

First, the tax system on goods and services has been improved. Since 2013, the Ministry of Finance and the State Administration of Taxation have promoted the pilot project of changing business tax into VAT. The Provisional Regulations on business tax were repealed in 2017. In addition, the Ministry of Finance and the State Administration of Taxation have successively adjusted some items and tax rates of consumption tax and reduced import tariffs.

Second, the income tax system has been perfected. In 2017 , the Standing Committee of the National People's Congress amended individual provisions of the Enterprise Income Tax Law, including accelerated depreciation of fixed assets for some key industries, reduction of enterprise income tax for small and micro enterprises, and improvement of the pre-tax deduction ratio of enterprise research and development expenses. In 2018, the Standing Committee of the National People's Congress amended the Individual Income Tax Law to adjust the pre-tax deduction and tax rate according to the comprehensive income tax.

Third, the property tax system has been improved. In 2016, the Ministry of Finance and the State Administration of Taxation comprehensively promoted the reform of resource tax. The main content of the reform is to expand the scope of taxation and the scope of application of Ad Valorem taxation methods. [8]

In addition, in 2016, the Standing Committee of the National People's Congress passed the "Environmental Protection Tax Law of the People's Republic of China", which would take effect from 2018. In 2017, the Standing Committee of the National People's Congress passed the "Tobacco Tax Law of the People's Republic of China" and the "Ship Tonnage Tax Law of the People's Republic of China", all of which would come into effect from July 2018.

\section{ii. The Design of Tax System During This Period}

China's tax system had a total of 18 kinds of taxes by 2018 , which could be roughly divided into the following four categories in accordance with the object of Taxation: First, goods and services tax, which included value-added tax, consumption tax, vehicle purchase tax and tariff. Second, income tax. It includes enterprise income tax, personal income tax and land value-added tax. Third, property tax. The property tax, urban land use tax, cultivated land use tax, deed tax, resource tax, vehicle and ship tax and ship tonnage tax were included. Fourth, other taxes. Including stamp duty, city maintenance and construction tax, tobacco tax and environmental protection tax. 


\section{The Change of Tax System Reform in Different Periods from the Data Perspective}

\subsection{The Amount of Tax Revenue in China in the Periods of Reform}

\subsubsection{The Amount of Tax Revenue in China from 1978 to 1993}

In 1993, China's tax revenue reached 425.53 billion yuan, an increase of 7.2 times over 1978. In 1993, China's fiscal revenue was 434.9 billion yuan and its GDP was 3567.32 billion yuan. Taxation accounts for $97.8 \%$ of fiscal revenue and $11.9 \%$ of GDP respectively. The former was 51.9 percentage points higher than 1978 and the latter was 2.3 percentage points lower than 1978. Among the tax revenues, goods and services tax revenue was 305.49 billion-yuan, accounting for $71.4 \%$, which was 12.2 percentage points lower than that in 1978; income tax revenue was 75.67 billion-yuan, accounting for $17.5 \%$, an increase of 7.1 percentage points over 1978; The property tax revenue was 15.07 billion-yuan, accounting for 3.4\%, an increase of 3.2 percentage points over 1978. In addition, agricultural tax and animal husbandry tax revenue was 9.02 billion-yuan, accounting for $2.1 \%$ of national tax revenue, which was 3.4 percentage points lower than that in 1978. [9]

\subsubsection{The Amount of Tax Revenue in China form 1994 to 2012}

In 2012, China's tax revenue reached 100614.43 billion yuan, an increase of 22.6 times over 1993. In 2012, China's fiscal revenue was 11725.35 billion-yuan and its GDP was 5403.67 billion-yuan. In this year, tax revenue accounted for $85.8 \%$ of fiscal revenue and $18.6 \%$ of GDP respectively. The former was 12 percentage points lower than that in 1993 and the latter was 6.7 percentage points higher than that in 1993. Among the tax revenues, goods and services tax revenue was 5965.95 billion-yuan, accounting for $57.8 \%$, which was 13.6 percentage points lower than that in 1993; income tax revenue was 3054.73 billion-yuan, accounting for $29.6 \%$, an increase of 12.1 percentage points over 1993; property tax revenue was 870.74 billion-yuan, accounting for $8.4 \%$, an increase of 5 percentage points over 1993. [10]

\subsubsection{The Amount of Tax Revenue in China Since 2012}

In 2017, China's tax revenue reached 144369.99 billion-yuan, an increase of $43.5 \%$ over 2012 . In 2017 , China's fiscal revenue was 17259.28 billion-yuan and its GDP was 827.12 billion-yuan. Tax revenue accounts for $83.6 \%$ of fiscal revenue and $17.5 \%$ of GDP, respectively, which were lower $2.2 \%$ and $1.1 \%$ respectively than those in 2012. Among the tax revenues, goods and services tax revenue was 7498.22 billion yuan, accounting for $51.9 \%$, which was 5.9 percentage points lower than 2012; income tax revenue was 4.8995 billion yuan, accounting for $33.9 \%$, an increase of 4.3 percentage points over 2012 ; property tax Revenue was $1,370.45$ billion yuan, accounting for $9.5 \%$, an increase of 1.1 percentage points over 2012. [11]

\subsection{The Growth and Structural Change of Tax Revenue}

\subsubsection{From the Perspective of Tax Categories}

The proportion of goods and services tax revenue in the national tax revenue decreased from $83.6 \%$ in 1978 to $51.9 \%$ in 2017, a decrease of 31.7 percentage points. The proportion of income tax revenue in the national tax revenue rose from $10.4 \%$ in 1978 to $33.9 \%$ in 2017 , an increase of 23.5 percentage points. The proportion of property tax revenue in national tax revenue rose from $0.2 \%$ in 1978 to $9.5 \%$ in 2017 , an increase of 9.3 percentage points.

\subsubsection{From the Perspective of Income Levels}

The proportion of central tax (referring to the taxes that all revenues are transferred to the central government) in the national tax revenue decreased from $15.4 \%$ in 1994 to $11.9 \%$ in 2017, a decrease of 3.5 percentage points; The proportion of local taxes (referring to the taxes that all revenues are transferred to the local government) and the central and local shared tax revenues in the national tax revenue rose from $9.7 \%$ and $74.9 \%$ in 1994 to $12.2 \%$ and $75.9 \%$ in 2017 respectively, which increased by $2.5 \%$ and $1 \%$ respectively.

\subsubsection{From the Perspective of Regional Structure}

The proportion of tax revenue from the eastern region in the national tax revenue rose from $61.3 \%$ in 1994 to $66.9 \%$ in 2017 , an increase of 5.6 percentage points. The proportion of tax revenue from the western region in the national tax revenue decreased from $19.9 \%$ in 1994 to $16.2 \%$ in 2017 , a decrease of 3.7 percentage points. The proportion of tax revenue in the central region in the national tax revenue decreased from $18.8 \%$ in 1994 to $16.9 \%$ in 2017 , a decrease of 1.9 percentage points.

\subsubsection{From the Perspective of Ownership Structure}

The proportion of tax revenue from state-owned enterprises and collective enterprises in the national tax revenue decreased from $68 \%$ and $15.8 \%$ in 1994 to $9.5 \%$ and $0.4 \%$ in 2017 respectively, which decreased by $58.5 \%$ and $15.4 \%$ respectively. The proportion of tax revenue from joint-stock enterprises, private enterprises and self-employed and foreign-related enterprises in the national tax revenue rose from $2.3 \%, 6.4 \%$ and $6.4 \%$ in 1994 to $49.4 \%, 18.1 \%$ and $18.7 \%$ in 2017 respectively, which increased by $47.1,11.7$ and 12.3 percentage points respectively.

\subsubsection{From the Perspective of Industrial Structure}

The proportion of tax revenue from the secondary industry in the national tax revenue decreased from $49.5 \%$ in 2012 to $43.6 \%$ in 2017 , a decrease of 5.9 percentage points. The proportion of tax revenue from the tertiary industry in the national tax revenue rose from $50.4 \%$ in 2012 to $56.3 \%$ in 2017 , an increase of 5.9 percentage points. [12] 


\section{Experience of Tax Reform in China in the Past 40 Years}

\subsection{Basic Objectives of China's Fiscal and Tax Reform in the Past 40 Years}

The basic goal of adhering to the tax system reform is to establish a tax system with fair tax burden, reasonable competition, rule of law, and openness and inclusiveness for the purpose of building a socialist market economy. The establishment of a socialist market economy must eliminate regional blockades and market separatism, and establish a nationally unified market, only in this way can we liberate and develop productive forces. Therefore, it's necessary to unify and complete the tax reform. Fair tax burden is an objective requirement for the development of socialist market economy, as well as social development and the improvement of people's living standards. The essence of market economy is competitive economy. Only when enterprises compete fully, then the market can be full with vigor and vitality. [13] Therefore, China's tax reform should be conducive to enterprise competition's promotion. China's 40 - year tax reform has always adhered to the principle of administering taxes according to law, openness and inclusiveness, and integrating with the international community, which is also the fundamental requirement of market economy.

\subsection{Guiding Ideas of Fiscal and Tax Reform in China in the Past 40 Years}

China's tax reform is closely linked to the economic system reform and has received strong support from all sectors of society. In the past 40 years, every major tax reform in China has been incorporated into National Strategic Planning, and has always been subordinated to and served the strategic needs of China's overall reform and opening up of China's economic system, as well as the strategic needs of macroeconomic development. In addition, every major tax reform extensively solicits the opinions of the society and the transparency of tax legislation has been continuously enhanced, which has received strong support from all sectors of society.

\subsection{The Way of Fiscal and Tax Reform in China in the Past 40 Years}

Tax system reform should be carried out in an orderly way and step by step, steadily implemented and gradually improved. Every tax reform in China is a gradual reform under the guidance of the country's long-term goals and plans, so as to avoid violent social unrest as much as possible. For instance, the reform of value-added tax was pushed forward step by step from the pilot of value-added tax transformation to the full realization of "replacement of business tax with value-added tax". In terms of the reform of enterprise income tax, first, unifying the income tax of foreign-funded enterprises, and then unifying the income tax of domestic-funded enterprises, and finally, the unification of the income tax of domestic-funded and foreign-funded enterprises, which has been gradually carried out. [14]

\section{Thoughts on Further Deepening China's Tax Reform}

\subsection{Optimizing Tax Structure}

In 2017, China's goods and services tax revenue was 8257.394 billion-yuan, accounting for $57.2 \%$ of the total tax revenue. Generally speaking, China's tax system is still mainly based on Taxation of goods and services, which does not meet the development requirements of the modern tax system. Indirect taxation is conducive to strengthening the macro-control function of Taxation and giving play to the neutral role of taxation. [15] Therefore, China should continue to play the dominant role of indirect tax in the future. At the same time, the direct tax, represented by personal income tax and real estate tax, plays an important role in narrowing the gap between rich and poor and promoting social equity. Therefore, China should further increase the proportion of direct tax and build a modern tax system conducive to social equity.

\subsection{Perfecting the Reform of Various Taxes}

\subsubsection{Value Added Tax}

Firstly, we should simplify the VAT system, abolish simple taxation methods for small-scale taxpayers, and maintain a fair competitive market environment. Secondly, we should innovate the way of VAT collection and management. Pay attention to information management when collecting VAT for tertiary industry. Thirdly, VAT should be levied from the place of production to the place of consumption.

\subsubsection{Individual Income Tax}

Individual Income Tax should be levied in a comprehensive and classified way. To further improve the contents and methods of special deduction, we should fully consider the cost of living by taxpayers, the expenditure on children's education, the expenditure on supporting the elderly and the expenditure on interest on ordinary self-housing loans. In terms of tax rate design, the first-class tax rate should be low, while the high-income groups should be subject to a high tax rate which should not exceed the current maximum tax rate of $45 \%$.

\subsubsection{Real Estate Tax}

The object of real estate tax collection includes not only the value of houses, but also the land value connected with them. To promote the reform of real estate tax, we must promote the legislation of real estate tax. Local governments are allowed to set up real estate tax system according to local conditions. We should adhere to the strategy of "first enterprise, then individual; first city, then countryside". Then, the design of tax system should broaden tax base and lower tax rate. At last, we should reduce the tax collection in real estate development and transaction and increase the tax collection in property ownership. 


\subsubsection{Excise Tax}

First of all, we should expand the scope of consumption tax, including some high energy consumption, high emission and high resource consumption products. Secondly, the reasonable level of consumption tax rate should be designed to form a big tax rate gap between environmental protection products and energy-consuming products and guide citizens to consume reasonably. Thirdly, the scope of consumption tax should be adjusted at any time with the development of economy and society. [16]

\subsection{Internationalization of China's Tax System}

Under the background of China's "one belt and one way" initiative and international tax reform, China's tax reform should pay more attention to following the international tax rules, encourage enterprises to face global development and realize the internationalization of China's tax system.

\section{Conclusion}

China's tax reform has gone through 40 years. China's tax system reform at all stages has been carried out under the circumstances of China's economic transformation from planned economy to market economy. Every reform has made great breakthroughs in the construction of tax system, the growth of total tax revenue, the structural adjustment of tax system and the function of tax revenue. Looking forward to the future, because the economic and social situation will be more complicated, the functions of the government need to be thoroughly transformed, and there are still many problems in China's tax system, so China's reform will continue. In the future, China's tax system reform will be based on China's national conditions, and China's tax system design will more reflect the Chinese characteristics.

\section{References}

[1] LiuZuo, 2018. 40 Years of Tax Reform in China. China Taxation, 11, 26-30.

[2] Website of Ministry of Finance of the People's Republic of China. http://www.mof.gov.cn/index.htm

[3] Xie Xuren, 2009. China's Fiscal 60 Years. Economic Science Press, Beijing.
[4] China Taxation Society. 40 Years of Tax Reform: Exploration and Enlightenment.

http://www.chinatax.gov.cn/n810219/n810744/n3947632/n394 7642/c3955594/content.html, 2018-12-19

[5] Zhao Quanhou, 2018. The Evolution Track and Stage Characteristics of China's Fiscal and Tax System Reform. Reform magazine, 290, 29-38.

[6] Bai Yanfeng, Luo Qing, 2018. Forty Years of Fiscal and Tax Reform: Review, Experience and Prospect. Journal of Hebei University, Mar (3), 73-82.

[7] Xinhua news agency. Review of Tax Reform in the Past 40 Years.

http://www.chinatax.gov.cn/n810219/n810744/n3428471/n342 8496/c3850228/content.html, 2018-10-31

[8] Yang Zhiyong, 2018. China's Public Finance from 1978 to 2018: Ideas and Changes. Finance and Trade Economy, 10, $5-16$.

[9] National Bureau of Statistics of the People's Republic of China, 1978-1993. China Statistical Yearbook, China Statistical Press, Beijing. Some of the data are calculated by the author.

[10] National Bureau of Statistics of the People's Republic of China, 1994-2012. China Statistical Yearbook, China Statistical Press, Beijing. Some of the data are calculated by the author.

[11] National Bureau of Statistics of the People's Republic of China, 2013-2017. China Statistical Yearbook, China Statistical Press, Beijing. Some of the data are calculated by the author. Part of the data is from the 2018 news on the website of the State Administration of Taxation.

[12] LiuZuo, 2018. A Brief Review of China's Tax Reform in the Past 40 Years. Collection of Research Papers on the History of Finance and Taxation in China, 1-10.

[13] Jin DongSheng. Basic Experiences of Tax Reform in China in the Past 40 Years. China Economic Times, 2018.12.14.

[14] Gao Peiyong, Liu Shangxi, Wu Junpei, etc., 2018. The Way to Reform China's Fiscal and Tax System. Economic Perspectives, 10, 5-20.

[15] Ma Haitao, Xiao Peng, 2018. Review and Prospect of China's Fiscal and Tax Reform in the Past 40 Years of Reform and Opening-up. Research on Local Finance, 11, 4-19.

[16] Ma Haitao, Hao Xiaojing, 2018. Modernized Economic System Construction and Tax System Reform. Tax research, 2, 5-11. 